\title{
Effects of Different Proportions of Dried Cafeteria Leftover Inclusion in a Concentrate Mix on Performance of Growing Pigs
}

\author{
Tesfaye Amene ${ }^{1}$, Mengistu Urge ${ }^{2}$, Mitiku Eshetu $^{2}$ and Diriba Diba ${ }^{3}$ \\ ${ }^{1}$ Department of Animal and Range Sciences, College of Agriculture and Natural Resource Management, \\ Mada Walabu University, P.O. Box: 247, Bale Robe, Ethiopia \\ ${ }^{2}$ School of Animal and Range Sciences, College of Agriculture and Environmental Sciences, \\ Haramaya University, P.O. Box: 138, Dire-Dawa, Ethiopia \\ ${ }^{3}$ Department of Animal Sciences, Faculty of Agriculture, Wollega University, P.O. Box: 395, Nekemte, \\ Ethiopia
}

\begin{abstract}
An experiment was conducted to evaluate the effect of inclusion of dried Cafeteria leftover (DCLO) at various levels in concentrate mix (CM) on feed intake, digestibility, average daily gain (ADG), feed conversion ratio (FCR), carcass characteristics, and economic benefits of weaned pigs at Haramaya university piggery. Twenty Yorkshire pigs with initial live weight of $19.89 \pm 0.297 \mathrm{~kg}($ mean \pm SE) were randomly assigned to four dietary treatments in a completely randomized block design each with five replicates. The experimental rations were sole CM (mixture of maize grain, wheat short, wheat bran, noug seed cake, soybean mill, vitamin premix and salt), replacement of the concentrate with DCLO at different proportions as (33\%CM and 67\% DCLO; 67\% CM and 33\% DCLO) and feeding with only sole DCLO. The mean feed intake ranged $1.6-1.82 \mathrm{~kg} /$ day and ADG was $0.4-0.64 \mathrm{~kg} /$ day. The least feed intake was for sole DCLO $(P<0.05)$ and the highest for $67 \%$ CM:33\%DCLO. The FCR $(w / w)$ was lowest $(\mathrm{P}<0.05)$ for pigs fed 33\% DCLO diet, and pigs fed 67\% DCLO:33\%CM achieved highest FCR. Crude protein digestibility did not differ between treatments, but DM, EE and CF digestibility increased with increasing level of DCLO in the diets. The mean carcass weight $(43.7 \mathrm{~kg}-57.02 \mathrm{~kg})$ was highest in $67 \% \mathrm{CM}$ but lowest in sole DCLO. Back fat thickness $(2.4 \mathrm{~cm}-$ $3.2 \mathrm{~cm}(\mathrm{SEM}= \pm 0.03)$ ) was lowest in sole $\mathrm{CM}$ but highest in sole DCLO. The highest and lowest $(P<0.05)$ rib eye area $\left(23.9 \mathrm{~cm}^{2}-31.9 \mathrm{~cm}^{2}(\mathrm{SEM}= \pm 0.81)\right)$ were recorded for sole $\mathrm{CM}$ and sole DCLO, respectively. Cost of feed per $\mathrm{kg}$ weight gain was declined significantly $(P<0.01)$ with increasing level of DCLO. Despite the lower production cost of sole DCLO groups, the pigs showed lower performance and this must have contributed to lowest net return of the groups. Thus, it is concluded that DCLO can replace the conventional concentrate mix up to $67 \%$ without adverse effect on pig performance.
\end{abstract}

Copyright@2016 STAR Journal, Wollega University. All Rights Reserved.

Article Information Article History:

Received : 02-10-2016

Revised : 24-12-2016

Accepted : 26-12-2016

Keywords:

Carcass

Digestibility

Live Weight Gain

Nutritive Value

Profitability

*Corresponding Author:

Tesfaye Amene

E-mail:

tesfuam@gmail.com

\section{INTRODUCTION}

Attaining and sustaining food security are among the major concerns of world leaders across the globe. In the year 2013, about 842 million people in the world were unable to meet their nutritional requirements (FAO et al, 2013). Governmental programs, policies and projects are therefore aimed at ensuring regular food supply (especially those with high biological values like animal protein), local availability of food stuffs, food safety, affordability and accessibility. These goals have mounted pressure on livestock industries in devising means of increasing productivity and as well meeting the consumers' preference. Based on this demands, there has been a rise in the production of foods of animal origin, particularly from poultry and pigs in the world. In this regard, poultry accounts for about 34 percent and pork more than 40 percent share of the global meat protein market (FAOSTAT, 2012).
The world's tendency to increase pig production as a protein source of high quality has been promoted more in developing countries, which is necessitated by factors such as population increases, more demand for meat and increased consumption as rates of poverty decline (FAO, 2013). Nevertheless, increased animal production is accompanied by increased demands for feeds, particularly for ingredients which have high protein and energy values. This may be, however difficult to achieve under the scenario where population is ever increasing and production of grains per unit area remain low, particularly in developing countries leaving little opportunity of having surplus grains to formulate livestock feeds economically (Christopher et al., 1997). According to FAO (2011), increment of monogastric animal production and the more intensive feeding systems with improved genotypes resulted in relatively greater demand for higher quality concentrate feeds. Thus, availability and 
Tesfaye Amene et al.,

supply of grains and protein foodstuffs is likely to become more limited (Close, 1993; Amaefule et al., 2006).

One of the options to cope up with this problem is to partially replace the conventional concentrate feeds by cafeteria leftovers. With new technology, waste along the human food supply chain could be used as a partial substitute for cereal in animal feed (FAO, 2011). Apart from its importance in animal feed, it also supports a growing green economy and greatly reduces pressures on biodiversity, environments and water resources, a truly 'win-win' solution (FAO, 2011). In accordance, studies by Luu et al. (2003) have shown that good economic return in pig production can be achieved by use of local feed resources instead of commercial concentrates. The use of by-products from agricultural, industrial processing and left over, such as cafeteria left over (Luu et al., 2000) is a good alternative which can help improve producers' economic returns. The use of food wastes as animal feed is an alternative of high interest since it produces an environmental and public benefit besides reducing the cost of animal production (Westendorf et al., 1998; Myer et al., 1999; Westendorf, 2000).

Although, the chemical composition of food leftover is variable, food wastes are generally high in fat and moderately high in protein and ash (Korneygay et al., 1970; Myer et al., 1999). The digestibility of nutrients in food wasted is generally not poor. Westendorf and Dong (1997) reported high protein digestibility in food waste diet than in a corn-soybean meal diet (88.2\% vs. $84.3 \%)$. Likewise, Myer et al. (1999) reported moderately higher protein, digestibility and available lysine in dried food waste relative to soybean meal, which is known to be excellent for these nutrients. Food leftovers are widely available in higher learning institutions and colleges' cafeteria, private restaurants and hotels and private cafeteria in Ethiopia. However, information on the use of the mixture of cafeteria leftover with concentrate as swine ration is generally scant and it is not studied under Ethiopian condition to make recommendation for use by producers. Thus, this experiment was conducted to investigate the effect of dried cafeteria leftover inclusion in conventional concentrate mixture on growing pig performance and economic benefits.

\section{MATERIALS AND METHODS}

\section{Description of the Study Area}

The experiment was conducted at Haramaya University pig farm which is located at $42^{\circ} 3^{\prime} \mathrm{E}$ longitudes, $9^{0} 26^{\prime} \mathrm{N}$ latitude, altitude of 1980 m.a.s.l and a distance of $515 \mathrm{~km}$ east of Addis Ababa. The mean annual rainfall of the area amounts to $780 \mathrm{~mm}$ and the average minimum and maximum temperatures are 8.5 and $23.4{ }^{\circ} \mathrm{C}$, respectively (Mishra et al., 2004).

\section{Experimental Animals and their Management}

Twenty healthy growing Yorkshire pigs with an average initial body weight of $19.89 \pm 0.297 \mathrm{~g}$ (Mean \pm SE) were selected from the University piggery. All animals
Sci. Technol. Arts Res. J., Jan-March 2016, 5(1): 27-34

were dewormed with Ivermectin injection, sprayed with Diazinone against external parasites and vaccinated against foot and mouth (FMD) disease before starting the experiment. The pigs were housed and handled in an individual pen furnished with feed and water troughs. The pigs were blocked based on their initial body weight into four blocks of five pigs, and each animal within each block were randomly assigned to one of the four dietary treatments. The pigs were individually housed in $1.2 \mathrm{mx}$ $0.7 \mathrm{~m} \times 0.96 \mathrm{~m}$ concrete room. Feeds were provided twice a day at 7:30 AM and 3:30 PM ad libitum and water was provided free access. The pigs were weighed individually at the beginning and subsequently every 7 days during the experimental period. Based on their body weight change, the feed offered to individual pig was adjusted to ensure that they obtained feed at a rate of $4 \%$ (Okeke, 2007) of their body weight during the subsequent week days. Feed refusals were collected, weighed and recorded every morning at 7:00 AM before offering the next ration. The experiment was conducted for 90 days.

\section{Dietary Treatments}

The ingredients used in the rations formulation were maize grain, wheat short, wheat bran, noug seed cake, soybean mill, cafeteria leftover, vitamin premix and salt. The food leftover was taken from Haramaya University students' cafeteria. The wet cafeteria leftover was sundried for four consecutive days by sparsely spreading on canvas. It was hand stirred four times a day to enhance better drying and put indoors every evening to minimize reabsorption of moisture. The dried cafeteria leftover was tested weekly to determine whether its moisture content is at the recommended level for safe storage. The moisture content of the cafeteria leftover was $60-65 \%$ and $8.9 \%$ before and after drying, respectively. After the amount of dried cafeteria left over (DCLO) required for the entire experiment was secured, it was thoroughly mixed and placed in sacks until it was ground and used. The main constituents of the cafeteria left over were the traditional Ethiopian pancake "Enjera" which is made up of a cereal grain "Teff" and bread made of wheat flour.

All the ingredients, except soybean meal, wheat short, wheat bran, and vitamin premix were hummer milled to pass a $3 \mathrm{~mm}$ sieve size and made ready for formulation of the experimental rations. Experimental rations are shown in Table 1. Except cafeteria leftover alone, the three treatment rations were formulated on an isonitrogenous basis having 18\% crude protein. Ration 1 (T1) contains only mixture of conventional concentrate ingredients. DCLO inclusion was $33 \%$ and $67 \%$ in rations 2 (T2) and ration 3 (T3) in daily offer, respectively and ration 4 was sole DCLO (100\%). Vitamin premix was added equally to rations 1,2 and 3 while not included in sole DCLO. Salt was added based on the level of DCLO and CM in the ration, and the sole CM, 33\% DCLO and 67\% DCLO received salt accordingly, but laboratory test showed that $100 \%$ DCLO contain the recommended amount of salt and did not require additional salt.

Table 1: Initial ingredients used in the ration formulation of growing pigs

\begin{tabular}{lcccc}
\hline \multirow{2}{*}{ Ingredients } & \multicolumn{4}{c}{ Treatments (\% DM) } \\
\cline { 2 - 5 } & T1 & T2 & T3 & T4 \\
\hline Concentrate mix (\%) & 100 & 67 & 33 & - \\
Dried Cafeteria left over (\%) & - & 33 & 67 & 100 \\
Vitamin premix & 0.1 & 0.1 & 0.1 & - \\
Salt & 0.2 & 0.1 & 0.1 & - \\
\hline Total (\%) & $\mathbf{1 0 0}$ & $\mathbf{1 0 0}$ & $\mathbf{1 0 0}$ & $\mathbf{1 0 0}$ \\
\hline \multicolumn{4}{c}{$(-)$ indicates no inclusion of the ingredient }
\end{tabular}


Tesfaye Amene et al.,

\section{Feed Sampling and Processing}

Representative samples of feed offered were collected once per day and pooled by feed type for the entire experimental period. After thorough mixing, the pooled samples were sub-sampled and dried at $60^{\circ} \mathrm{C}$ to constant weight for chemical analysis. The dried feed samples were finely ground to pass through $1 \mathrm{~mm}$ sieve size and stored in an air tight plastic bags pending chemical analysis. Dry matter (DM) content of the feed was determined by drying representative feed samples in a forced draft oven at $105^{\circ} \mathrm{C}$ overnight.

\section{Feed Intake, Body Weight Change and Feed Conversion Ratio}

Daily diets were weighed and recorded while offering to the animals. Feed refusals were collected and weighed to determine daily feed intake. Initial body weight of weaned pigs was recorded on the first day of the experiment and every week in the morning before feed offering during the entire experiment using animal weighing scale. Weekly body weight measurement was partly adjusted for the amount of feed offer. Feed conversion ratio (FCR) was determined by dividing the amount of feed intake day ${ }^{-1}$ to daily body weight gain of the animal.

\section{Apparent Digestibility}

Digestibility trial was conducted at the beginning of the experiment after an adaptation period of 15 days to the experimental pens and diets. The animals were adjusted to carrying of fecal bags for seven days and feces were collected for another seven consecutive days. The feces collected each day per animal were weighed and 15\% was sub-sampled and stored frozen at $-20^{\circ} \mathrm{C}$, and pooled over the collection period. At the end of the digestion trial, the fecal sample from each animal was thoroughly mixed and $15 \%$ composite sample was taken and thawed to room temperature, weighed and dried at $60{ }^{\circ} \mathrm{C}$ for 72 hours. The partially dried sample of feces were ground to pass $1 \mathrm{~mm}$ sieve and stored in airtight polyethylene bag pending for chemical analysis.

\section{Carcass Evaluation}

At the end of the feeding trial, four pigs from each treatment were fasted for 12 hours and slaughtered for carcass analysis. Animals were weighed immediately before slaughter. The pigs were laid by grasping the leg or opposite side and rested on its back. An incision of about 2 to 4 inches long was made from the point of the breast bone forward on the exact middle of the neck to exactly harm the heart. As soon as the pig's body bled completely and life was extinct, the blood on the carcass was wiped off and the hair was removed by burning using pressurized fire. After dressing and evisceration, hot carcass weight was taken and recorded to assess dressing percentage on slaughter body weight basis. The offal's were removed after an incision given in the middle of the belly from abdomen to thoracic cavity and cut open. The body cavity was thoroughly washed with cold water. Empty stomach, large intestine, Kidney, heart, lung and liver weight were taken. Kidney fat was measured after detaching the kidney from its covering fat. The carcass length $(\mathrm{cm})$ was measured in the straight line from the cranial (anterior) tip of the aitch bone to the cranial edge of the first rib and next to the vertebra. The back fat thickness was measured as the average of first rib, last rib and last lumber vertebra fat thickness. The rib eye area
Sci. Technol. Arts Res. J., Jan-March 2016, 5(1): 27-34

measurement was done at $10^{\text {th }}$ and $11^{\text {th }}$ ribs after the carcass was cut perpendicular to the vertebral bone.

\section{Diet Profitability}

The partial budget analysis was employed (Upton, 199) to determine the profitability of incorporation of different proportions of DCLO in the diets of pigs. The partial budget analysis involved calculation of the variable costs and benefits. Partial budget analysis was used to measure the pig, feed and labor costs and the profit after the experiment, or differences between gains and losses for the proposed change. The net income (NI) was calculated by subtracting total variable cost (TVC) from total return (TR) and calculated as NI=TR-TVC.

The change in net income $(\Delta \mathrm{NI})$ was calculated as the difference between the changes in total variable cost $(\Delta T V C)$, and is calculated as follows.

$$
\Delta \mathrm{NI}=\Delta \mathrm{TR}-\Delta \mathrm{TVC}
$$

The marginal rate of return (MRR) measured the increase in net income $(\Delta \mathrm{NI})$ associated with each additional unit of expenditure ( $\triangle T V C)$

$$
\mathrm{MRR}=\Delta \mathrm{NI} / \Delta \mathrm{TVC}
$$

\section{Chemical Analysis of Feeds}

Feed samples were analyzed for dry matter (DM), ether extract (EE), crude fiber (CF) and ash content according to AOAC (1990). Nitrogen content of the feed was determined using Kjeildhal procedure to calculate crude protein $(C P)$ value as $\mathrm{CP}=\mathrm{N}^{*} 6.25$. Atomic Absorption Spectrophotometer method for Calcium and Colorimetrical method for phosphorus determination were used. Metabolizable energy (ME) of the experimental diets was determined by indirect methods, according to Wiseman (1987) as follows:

$$
\mathrm{ME}(\mathrm{Kcal} / \mathrm{kg} \mathrm{DM})=3951+54.4 \mathrm{EE}-88.7 \mathrm{CF}-40.8 \text { Ash }
$$

\section{Statistical Analysis}

The data collected were analyzed using the general linear model (GLM) procedure of Statistical Analysis System (SAS, 2008) version 9.1.3 software program. When the analysis of variance indicated the existence of significant difference among treatment means, Duncan's Multiple Range Test (DMRT) was employed to separate the means at $\alpha=0.05$. The following model was used for the experiment.

$$
Y i j=\mu+T i+B j+e i j
$$

Where $Y_{i j}=$ represents the $j^{\text {th }}$ observation (experimental unit) taken under treatment $\mathrm{I} ; \mu=$ over all means; $\mathrm{T}_{i}=\mathrm{i}^{\text {th }}$ treatment effect; $B j=$ block effect and $e_{i j}=$ is a random error component that incorporates all other sources of variability in the experiment.

\section{RESULTS}

\section{Chemical Analysis and Nutritive Value}

The DM content of all ingredients falls within the narrow range of $90-93 \%$ (Table 2). The CP content of DCLO was slightly higher than that for maize grain. DCLO has the highest EE content than the other ingredients with the least for wheat short. Noug seed cake has the highest ash and crude fiber among all other ingredients. Ca content was highest in pigs fed DCLO but $P$ is for those consumed soy bean meal. 
Table 2: Chemical composition of feed ingredients used in the experimental ration formulation (DM basis)

\begin{tabular}{ccccccc}
\hline \multirow{2}{*}{$\begin{array}{c}\text { Chemical } \\
\text { Components }\end{array}$} & DCLO & $\begin{array}{c}\text { Noug seed } \\
\text { Cake }\end{array}$ & $\begin{array}{c}\text { Soya bean } \\
\text { Meal }\end{array}$ & $\begin{array}{c}\text { Maize } \\
\text { Grain }\end{array}$ & $\begin{array}{c}\text { Wheat } \\
\text { Short }\end{array}$ & $\begin{array}{c}\text { Wheat } \\
\text { Bran }\end{array}$ \\
\cline { 2 - 7 } & 91.2 & 92.1 & 93 & 90 & 90 & 90.5 \\
DM & 9 & 29.6 & 39.0 & 8.5 & 14.7 & 16 \\
CP & 13 & 8.1 & 9.2 & 6.2 & 3.3 & 4.2 \\
EE & 7.6 & 9.1 & 5.8 & 5.9 & 5.5 & 6.1 \\
ASH & 3.6 & 18.3 & 5.7 & 2.8 & 9.9 & 12.4 \\
CF & 0.8 & 0.35 & 0.35 & 0.02 & 0.19 & 0.2 \\
Ca & 0.71 & 0.32 & 0.83 & 0.82 & 0.78 & 0.79 \\
P & 4028.8 & 2395.8 & 3710.95 & 3798.7 & 3030.7 & 2402 \\
ME(Kca/kg) & (K) & dry mater; CP = crude protein; EE = ether extract; CF= crude fiber; Ca = calcium; P = phosphorus;
\end{tabular}

\section{Feed Intake}

The total and average daily feed intake in all treatments consistently increased with increase in proportion of DCLO in the diet (Table 3). Nevertheless, it was lower $(\mathrm{P}<0.001)$ for pigs consumed sole DCLO diet but no difference was observed between pigs fed the other treatment diets. The $\mathrm{CP}$ intake (CPI) and CF intake $\mathrm{CFI}$ ) was higher for pigs offered CM mixes than DCLO.

Table 3: Nutrient intake of pigs fed ration containing different levels of dried cafeteria leftover

\begin{tabular}{|c|c|c|c|c|c|c|}
\hline \multirow{2}{*}{ Items } & \multicolumn{6}{|c|}{ Treatments } \\
\hline & T1 & T2 & T3 & T4 & SEM & SL \\
\hline ADFI (Kg/day) & $1.7^{\mathrm{a}}$ & $1.79^{\mathrm{a}}$ & $1.8^{\mathrm{a}}$ & $1.6^{\mathrm{b}}$ & 0.03 & 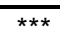 \\
\hline $\mathrm{TFI}(\mathrm{kg})$ & $156.5^{\mathrm{a}}$ & $161.1^{\mathrm{a}}$ & $163.7^{\mathrm{a}}$ & $144^{\mathrm{b}}$ & 0.31 & $* *$ \\
\hline OMI(kg/day) & $1.7^{\mathrm{a}}$ & $1.73^{\mathrm{a}}$ & $1.75^{\mathrm{a}}$ & $1.5^{\mathrm{b}}$ & 1.35 & $\star * \star$ \\
\hline CPI (kg/day) & $0.31^{a}$ & $0.31^{a}$ & $0.32^{\mathrm{a}}$ & $0.27^{b}$ & 1.42 & $* * *$ \\
\hline CFI (kg/Day) & $0.22^{\mathrm{a}}$ & $0.2^{\mathrm{a}}$ & $0.14^{b}$ & $0.1^{\mathrm{c}}$ & 0.34 & 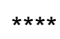 \\
\hline $\mathrm{MEI}(\mathrm{Kcal} / \mathrm{kg})$ & $3924.6^{a}$ & $3935.52^{\mathrm{a}}$ & $3942^{a}$ & $4028.8^{b}$ & 0.08 & ** \\
\hline
\end{tabular}

${ }^{\mathrm{abc}}$ Means within the same row bearing different superscripts are significantly different; ${ }^{*}=\mathrm{P}<0.05$

$\star \star=P<0.01,{ }^{* \star *}=\mathrm{P}<0.001,{ }^{\star \star \star *}=\mathrm{P}<0.0001 ; \mathrm{SEM}=$ standard error of mean; $\mathrm{SL}=$ significant level;

ns= non-significant; ADFI = average daily feed intake; TFI = total feed intake; CPI= crude protein intake $\mathrm{CFI}=$ crude fiber intake; $A D G$ = average daily gain; T1=sole concentrate mix; T2=33\% DCLO:67\% CM; T3=67\% DCLO:33CM and T4=100\% DCLO; CM= concentrate mix.

\section{Nutrient Digestibility}

The digestibility of $\mathrm{CP}$ is not affected by levels of DCLO inclusion in the ration but that of the DM, CF and

EE increased with increasing DCLO levels in the dietary mix.

Table 4: Nutrients digestibility in pigs fed ration containing different levels of DCLO

\begin{tabular}{|c|c|c|c|c|c|c|}
\hline \multirow{2}{*}{ Parameters } & \multicolumn{4}{|c|}{ Treatments } & \multirow[t]{2}{*}{ SEM } & \multirow[t]{2}{*}{ SL } \\
\hline & T1 & $\mathrm{T} 2$ & T3 & T4 & & \\
\hline DM & $85.8^{b}$ & $86.3^{b}$ & $89.3^{a}$ & $91.7^{\mathrm{a}}$ & 0.38 & ** \\
\hline $\mathrm{CP}$ & 87.4 & 87.82 & 87.0 & 88.6 & 0.34 & ns \\
\hline CF & $50.6^{d}$ & $54.4^{c}$ & $60.8^{b}$ & $67.6^{a}$ & 1.51 & ** \\
\hline EE & $61.7^{d}$ & $75.4^{c}$ & $86.5^{b}$ & $90.2^{\mathrm{a}}$ & 2.48 & $\star * *$ \\
\hline
\end{tabular}

${ }^{\mathrm{ab}}$ Means within the same row bearing different superscripts are significantly different; ${ }^{*}=P<0.05$;

$* *=\mathrm{P}<0.01 ; * * *=\mathrm{P}<0.001 ; \mathrm{ns}=$ not significant; $\mathrm{DM}=$ dry matter; $\mathrm{CP}=$ crude protein; $\mathrm{EE}=$ ether extract; $\mathrm{CF}=$ crude fiber; $\mathrm{DCLO}=$ dried cafeteria leftover; $\mathrm{SL}=$ significant level; $\mathrm{SE}=$ standard error of mean;

T1=sole concentrate mix; T2=33\% DCLO:67\% CM; T3=67\% DCLO:33\%CM and T4=100\% DCLO.

\section{Body Weight Change and Feed Conversion Ratio}

The total and average daily body weight gain (ADG) of pigs was positive for all treatments (Table 5). The final weight, TBW gain and average daily gain (ADG) of the pigs were increased with increase in levels of DCLO in the dietary mixture except for sole DCLO diet. The FCR was in reverse trend with $A D G$ of the pigs.

Table 5: Body weight change and feed conversion ratio in pigs fed ration containing different levels of DCLO

\begin{tabular}{lcccccc}
\hline \multirow{2}{*}{ Items } & \multicolumn{7}{c}{ Treatments } \\
\cline { 2 - 7 } & T1 & T2 & T3 & T4 & SEM & SL \\
\hline Initial weight (kg) & 19.8 & 19.9 & 19.9 & 19.9 & 1.13 & ns \\
Final weight (kg) & $68.3^{\mathrm{b}}$ & $70.0^{\mathrm{b}}$ & $77.4^{\mathrm{a}}$ & $60.0^{\mathrm{c}}$ & 1.68 & $\star \star \star$ \\
TBW gain (kg) & $48.4^{\mathrm{b}}$ & $50.1^{\mathrm{b}}$ & $57.3^{\mathrm{a}}$ & $40.0^{\mathrm{c}}$ & 1.32 & $\star \star \star$ \\
ADG (Kg/day) & $0.54^{\mathrm{b}}$ & $0.56^{\mathrm{b}}$ & $0.64^{\mathrm{a}}$ & $0.40^{\mathrm{c}}$ & 0.01 & $\star \star$ \\
FCR (Feed/Gain) & $3.3^{\mathrm{b}}$ & $3.2^{\mathrm{b}}$ & $2.86^{\mathrm{a}}$ & $4^{\mathrm{c}}$ & 0.05 & $*$ \\
\hline
\end{tabular}




\section{Carcass Characteristics}

Feeding pigs with ration containing 67\% CM and 33\% DCLO significantly improved $(P<0.01)$ carcass weight and carcass length (Tables 6) above all other treatments. Dressing percentage $(P<0.01)$ and backfat thickness $(p<0.05)$ were consistently increased with increase in
DCLO levels in the diet. However, the results for rib-eyearea $(p<0.01)$ showed the opposite trend. Pigs consumed $67 \%$ DCLO and sole DCLO rations had lower weights of empty stomach $(P<0.01)$, heart $(P<0.05)$ and large intestine $(P<0.01)$ than the other groups.

Table 6: Carcass characteristics of pigs fed ration containing different levels of DCLO

\begin{tabular}{|c|c|c|c|c|c|c|}
\hline \multirow[b]{2}{*}{ Variables } & \multicolumn{6}{|c|}{ Treatments } \\
\hline & T1 & T2 & T3 & T4 & SEM & SL \\
\hline Carcass Weight (kg) & $48.4^{\mathrm{bc}}$ & $50.4^{b}$ & $57^{\mathrm{a}}$ & $43.7^{c}$ & 1.38 & $\star \star$ \\
\hline Carcass length (cm) & $70.2^{\mathrm{a}}$ & $71.2^{\mathrm{a}}$ & $71.8^{\mathrm{a}}$ & $66.9^{b}$ & 1.42 & * \\
\hline Dressing Percentage & $68.1^{b}$ & $68.9^{b}$ & $73^{a}$ & $73.9^{\mathrm{a}}$ & 0.55 & ** \\
\hline Back Fat Thickness (cm) & $2.4^{b}$ & $2.46^{b}$ & $2.5^{\mathrm{b}}$ & $3.2^{\mathrm{a}}$ & 0.03 & * \\
\hline Rib eye area $\left(\mathrm{cm}^{2}\right)$ & $31.9^{a}$ & $31.4^{\mathrm{a}}$ & $29.6^{\mathrm{a}}$ & $23.9^{b}$ & 0.81 & ** \\
\hline Empty stomach (kg) & $2.3^{\mathrm{a}}$ & $2.1^{\mathrm{a}}$ & $1.8^{\mathrm{b}}$ & $1.4^{\mathrm{c}}$ & 2.5 & ** \\
\hline Large intestine $(\mathrm{kg})$ & $2.1^{\mathrm{a}}$ & $2^{\mathrm{a}}$ & $1.6^{\mathrm{b}}$ & $1.3^{c}$ & 1.61 & ** \\
\hline Kidney Fat (g) & $65^{b}$ & $68^{\mathrm{ab}}$ & $70^{\mathrm{a}}$ & $71.2^{\mathrm{a}}$ & 1.1 & * \\
\hline Liver Weight (g) & $1060^{c}$ & $1130^{c}$ & $1230^{b}$ & $1380^{\mathrm{a}}$ & 3.77 & ** \\
\hline Heart Weight (g) & $326^{a}$ & $322.2^{\mathrm{a}}$ & $310^{b}$ & $294^{c}$ & 3.65 & $\star$ \\
\hline Kidney Weight (g) & 344 & 339 & 341 & 338 & 4.7 & ns \\
\hline Lung Weight (g) & 982 & 978 & 979.6 & 980.5 & 11.63 & ns \\
\hline
\end{tabular}

\section{Profitability Analysis}

Ration containing different levels of DCLO was economically feasible than the concentrate mix in feed cost/kg per pig (Table 7). Pigs fed sole CM had the lowest net return compared to the other ration combinations and the economic return was more promising for pig fed $67 \%$ DCLO containing ration.

Table 7: Economics of pigs fed ration containing different levels of dried cafeteria leftover

\begin{tabular}{|c|c|c|c|c|}
\hline \multirow{2}{*}{ Variables } & \multicolumn{3}{|c|}{ Treatments } & \multirow[b]{2}{*}{ T4 } \\
\hline & T1 & T2 & T3 & \\
\hline Pigs Cost (birr/pig) & 794 & 796 & 794.8 & 798 \\
\hline Total Feed Consumed (kg/pig) & 179 & 174 & 182 & 160 \\
\hline Total Feed Cost (birr/pig) & 970.2 & 794.8 & 510.3 & 50 \\
\hline Transport Cost (birr/pig) & 120 & 70 & 36 & 20 \\
\hline Average Carcass Weight (kg/pig) & 50.42 & 48.39 & 59.02 & 38.7 \\
\hline Price/kg of Carcass (at HU, birr/kg) & 50 & 50 & 50 & 50 \\
\hline Labor Cost (birr/pig) & 0 & 50 & 100 & 200 \\
\hline Total feed cost (birr) (TVC) & 1090.2 & 914.8 & 646.3 & 430 \\
\hline Gross income (birr/pig) & 2521 & 2419.5 & 2951 & 1935 \\
\hline Total returns (birr/ pig) (NI) & 1727 & 1623.5 & 2156.1 & 1137 \\
\hline Net return (birr/Pig) & 636.8 & 708.7 & 1509.8 & 707 \\
\hline Change in total return ( $\Delta \mathrm{TR})$ & - & 103.5 & 429.1 & 590 \\
\hline Change in net income $(\Delta \mathrm{NI})$ & - & -71.9 & -873 & -70.2 \\
\hline Change in total variable cost $(\Delta T V C)$ & - & 175.4 & 443.9 & 660.2 \\
\hline $\operatorname{MRR}(\Delta \mathrm{NI} / \Delta \mathrm{TVC})$ & - & -41 & -196.7 & -10.6 \\
\hline $\begin{array}{r}\text { TVC = total variable cost; MF } \\
\text { HU = Haramaya university; } \\
\text { 33\%DCLO = concentrate mix }(67 \% \\
67 \% \text { DCLO } \% \text { concentrate mix }(34 \\
\text { T4 = dried cafeteria leftover a }\end{array}$ & $\begin{array}{l}+ \text { dried } \\
\text { ne }(100 \%\end{array}$ & $\begin{array}{l}\text { l rate of re } \\
\text { rate mix al } \\
\text { eteria lefto } \\
\text { feteria left } \\
\mathrm{T}=\text { Treat }\end{array}$ & $\begin{array}{l}\text { urn; } \\
\text { ne; } \\
\text { er }(33 \%) \text {; } \\
\text { ver }(66 \%) \text {; } \\
\text { ent. }\end{array}$ & \\
\hline
\end{tabular}

\section{DISCUSSION}

\section{Chemical Composition of Feed Stuff}

The DM content of DCLO (91.2\%) compared to the average of the DM contents of the concentrate mixes $(91.12 \%)$ in the present study indicates comparable feed intake of the animals if offered the same weight of fresh matter. This was indicated by non-significant variations in TFI values among T1, T2 and T3. But, the CP value for sole DCLO is lower than a threshold required for optimum growth performance of swine (NRC, 1998) when used as a sole feed. NRC (1998) indicates that growing pigs require 17.2 to $20.0 \% \mathrm{CP}$ in the diet intake/day depending upon body size. The CP was also lower than the value, 15 to $23 \%$, reported by Westendorf et al. (1996) and $20-28 \%$ reported by Westendorf et al. (2000) for DCLO which is an attribute of the difference in the composition of the food waste used. The lower value of CP below the NRC (1998) standards and most reports from other studies indicates that DCLO in the current study needs supplementation with other diets of higher CP content. The higher ash content for DCLO in the present study could be due to addition of common salt during food cooking. In similar way, the highest EE in DCLO of the present study, as compared to the average value for other concentrate mixes, could be from the oils and /or butter added during 
Tesfaye Amene et al.,

food preparation in the cafeteria. Fat content of 17 to $24 \%$ and ash content of 3 to $6 \%$ were also reported in previous studies (Pond and Maner, 1984; Ferris et al., 1995; Westendorf et al., 1996).

\section{Feed Intake}

Absence of significant difference in feed intake among the groups fed with sole CM, 33\% DCLO and 67\% DCLO rations imply that feed intake was not hampered by the current levels of DCLO inclusion. Rather it was affected by levels of $\mathrm{CM}$ inclusion in the dietary mix. The higher organic matter intake (OMI) in pigs consumed $\mathrm{CM}$ compared to those fed DCLO is most likely due to less energy and/or nutrient concentration of the former compared to the later (McDonald et al 2007). On the other hand, since the CF content is higher in CM compared to DCLO, the intake is expected to be lower. However, it must be the microbes residing in the large intestine of pigs that assisted digestibility of fiber in $\mathrm{CM}$ so that intake was higher for pigs consumed CM (Lindberg, 2014). Such higher intake of fiber might have led to lower passage rate which ultimately resulted in lower digestibility in these groups (Klinger et al 2006). The digestibility of diets determine feed intake in growing pigs since it is highly correlated with the volume of digesta which in turn exerts an effect on gut filling capacity as well as the appetite (Whittemore, 1993; Noblet and LeGoff, 2001). On the other hand, dietary amino acid imbalance normally leads to marked reductions in both feed intake and growth rate in animals (D'Mello, 2003). Kyriazakis et al. (1990) reported growing pigs chose to eat more of a diet with a protein:energy ratio closer to the optimal for growth than one with a lower ratio. Increased viscosity in the small intestine might slow gut transit time due to suppressed intestinal contractions (Cherbut et al., 1990) which in turn leads to less mixing of dietary components with endogenous digestive enzymes affecting feed intake.

\section{Digestibility}

The increased DM digestibility with increase in levels of DCLO inclusion in the diets of pigs could be due to the existence of more soluble components in the later. In addition, since the later is cafeteria leftover, there was a chance for the food to be exposed to heat treatment during cooking and such kind of heat treatment increases digestibility of food (Almeida et al 2014). Absence of variation in crude protein digestibility among dietary treatments might be due in part to the influence of the proportion of the mix in the diets. The result is not congruent with the finding of Rivas et al. (1994) who noted decreased crude protein digestibility as the proportion of restaurant waste increased in the diet. The difference might be emanated due to differences between food leftover obtained at different time and variable nature of food waste. Digestibility of CF consistently increased from sole CM to sole DCLO. This could be due to higher intake of $\mathrm{CF}$ that consequently resulted in lower digestibility (Longe and Fagbenro-Byron, 1990) in pigs fed concentrate mixes. Digestibility of crude fiber is of a concern in swine diets because its poor digestibility can reduce the apparent digestibility of other dietary components such as protein (Myer et al., 1997). The digestibility of EE in sole DCLO fed pigs might be due to the lower level of CF and oil form of the lipid in DCLO added during cooking implying that increased level of DCLO in the ration increased EE digestibility. Higher levels of $E E$ in the present study must have also contributed to higher DM digestibility above. In previous
Sci. Technol. Arts Res. J., Jan-March 2016, 5(1): 27-34

studies, Rivas et al. (1994) and Westendorf (1998) noted superior digestibility of food waste EE as compared to the corn-soybean diet.

\section{Body Weight Change and Feed Conversion Ratio}

The lack of difference in ADG between pigs in 33\% DCLO and the sole CM implies the nutrient contents in these dietary treatments elicit similar body weight gain. Highest weight gain in group fed with the ration containing $67 \%$ DCLO can be attributed to the high energy content of DCLO and balanced nutrient as a result of the proportion between DCLO and CM at this level. The lower growth performance of pigs fed sole DCLO diet, while the energy content of the diet they consumed is highest, is an attribute of the lower crude protein contents and consequently to the deficiency of essential amino acids. Desehibwa (1999) also reported slow growth of pigs fed with diets of low CP. Chao et al. (2008) noted that market weight is delayed by 35 days in pigs fed fermented food waste. Energy density (NCR, 1998) and balances for specific nutrient groups such as carbohydrates, fat, and protein (Revell and Williams, 1993) are known to influence voluntary feed intake, which in turn affect the growth performance of pigs.

\section{Carcass Parameters}

The reason for inferior performance of pigs fed sole DCLO in carcass weight compared to those fed CM was that sole DCLO and 33\% DCLO has higher CF than $67 \%$ DCLO which affect intake and thereby body weight gain and subsequently reflected on carcass parameters. This result agrees with Chae et al., (2000) who reported improved feed quality through mixing with protein and energy source diets which improved digestibility and body weight gain. The feeding level, pattern and protein: energy ratio of the diet, together with the genetic growth potential of pigs determine the growth rate and composition of weight gain at both whole-body and muscle level and intern affect carcass weight (Lebret, 2008; Merck, 2008). The lower dressing percentage in pigs fed sole CM than pigs in $67 \%$ DCLO and sole DCLO $(P<0.01)$ was probably due to the increased weight of visceral organs, gastrointestinal tract and digesta, which was also noted in other studies where pigs were fed with high-fiber diets (Jorgensen et al., 1996; Qin et al., 2002). Pigs consumed sole DCLO has lower hot carcass weight than other groups which was attributed to low final body weight, which was the result of low nutrient contents of the diet and moderately high ash contents.

The highest backfat thickness in pigs fed sole DCLO was probably due to higher EE composition (Margareth et al., 1999) of the ration compared to the rest dietary treatments. This can also be explained as the sole DCLO ration has higher energy and lower protein contents as compared to other dietary treatments. This has negative impact on loin eye area when protein is below the recommended level. It is also reported by other authors that the effects of dietary energy on back fat thickness have been shown to be variable. In one of the study by Beaulieu et al. (2009) increased energy did not influence back fat thickness, but in another experiment, back fat thickness increased and loin area declined as dietary energy increased, which is similar to the present study. Peterson (1967) and Myer et al. (1999) found that food waste did not affect carcass parameter when nutrient requirement is met. Peterson (1967) found no differences in dressing percentage and loin-eye area among pigs fed 
Tesfaye Amene et al.,

food waste, food waste plus supplement, or concentrate diets having balanced nutrients. Apple et al., (2004) and Lawrence et al., (1994) also observed increased back fat thickness with increasing dietary energy. The effect of reduced $\mathrm{CP}$ concentration in the ration on carcass fatness is in agreement with Kay and Lee (1998). They reported increased level of back fat deposition in growing-finished pigs as protein level is reduced.

The higher empty stomach and large intestine values for the pigs fed conventional concentrate mix (sole $\mathrm{CM}$ ) could be attributed to the higher crude fiber level. Shurson (2003) reported significant changes in the mass of the gastrointestinal tract and other intestinal organs as a result of feeding diets based on $5 \%$ wheat bran, as a source of high insoluble fibre to pigs. The increase in the stomach and large intestine weights for concentrate mix diets alone observed in the current study is in line with the finding of Shurson et al. (2003) and Chesson (1995). But, absence of difference in lung weight and kidney weight between pigs fed all dietary treatment indicates that the changes of these organs are not directly related to fiber content of dietary treatments. If feed offered to animal has optimum nutrient for better animal performance, feed has no effect on carcass length, this could have been entirely dependent on the breed (Fisher and Boorman, 2003).

\section{Economic Analysis}

Despite the fact that sole DCLO is the cheapest diet it failed to promote optimum growth of the pigs to their genetic potential implying that its use as a sole diet cannot be justifiable. On the contrary, performance of pigs consumed $67 \%$ DCLO validate the importance of using DCLO in combination with other feed ingredients and it has good nutritive value for growing pigs when used as a replacement to convectional concentrates at even high level such as used in the present study.

The control treatment had the lowest net return $(636.8$ Birr/pig; One US Dollar is currently equivalent to about 21.4 Birr) compared to the ration containing DCLO, which was in the range of 707-1483.57 Birr. The result was even more promising for pig fed 67\% DCLO ration with the highest net return of 1509.8 Birr. This might be associated with the highest body weight gain and highest feed conversion efficiency. This result was coincided with Westendorf et al. (1998) who concluded that growing or finishing pigs fed food waste performed nearly as good as pigs fed a traditional diet when the food waste was supplemented with corn. The MRR implies that each additional unit of 1 Birr per pig cost increment resulted in 1 Birr and additional $0.41,1.96$ and $1.06 \mathrm{Birr} / \mathrm{pig}$ profit for $33 \%$ DCLO, 67\% DCLO and sole DCLO, respectively. The overall results of the present experiment show that replacement of concentrate mix by $67 \%$ DCLO can be used for formulation of least-cost swine ration without adverse effect on the overall pig performance.

\section{CONCLUSIONS}

This experiment demonstrated that inclusion of different levels of dried cafeteria left over in concentrate mix bring change on feed intake, feed conversion efficiency, body weight gain, nutrient digestibility, carcass parameters and economic benefit between treatments. Pigs fed on $67 \%$ DCLO diet improved these parameters as compared to pigs fed sole CM. Thus, it can be concluded that inclusion of DCLO in CM ration up to $67 \%$ DCLO would be a better feeding strategy to improve the performance of Yorkshire pigs.
Sci. Technol. Arts Res. J., Jan-March 2016, 5(1): 27-34

\section{Conflict of Interest}

None declared.

\section{REFERENCES}

Almeida, F.N., Htoo, J.K., Thomson, J., Stein, H.H. (2014). Effects of heat treatment on the apparent and standardized ileal digestibility of amino acids in canola meal fed to growing pigs. Animal Feed Science and Technology 187: 44-52

Amefule, K.U., Ibe, S.N., Abasiekong S.F., Onwudike, C. (2006). Response of weaner pigs to diets of different proportions and high levels of palm kernel meal and brewers dried grain in the humid tropics. Pakistan Journal of Nutrition 5: 461-466.

AOAC. (1990). Official methods of Analysis. AOAC (Association of Official Analytical Chemists), Ed. Washington, DC, pp. 69-88.

Apple, J.K., Maxwell, C.V., Brown, D.C., Friesen, K.G., Musser, R.E., Johnson, Z.B., Armstrong, T.A. (2004) Effects of dietary Lysine \& energy density on performance \&carcass characteristics of finishing pigs fed ractopamine. Journal of Animal Science 82(11): 3277- 3287.

Beauliea, A.D., Williams, N.H., Patience, J.F. (2009) Response to dietary digestible energy Concentration in growing pigs fed cereal grain -based diets. Journal of Animal Science 87(3): 965-976.

Chae, B.J., Choi, S.C., Kim, Y.G., Kim, C.H., Sohn, K.S. (2000). Effects of feeding dried food waste on growth and nutrient digestibility in growing-finishing pigs. AsianAustral. Journal of Animal Science 13(9): 1304-1308.

Chao, H.Y. and Li, F.C. (2008). Effect of level of fibre on performance and digestion traits in growing pigs. Animal Feed Science and Technology 144:279-291

Chesson, A. (1995). Dietary Fiber. In A. M. Stephen, \& I. O'Dea (Eds.), Food Polysaccharides and their Application (pp. 547-576). Marcel Dekker. New York.

Cherbut, C.E., Albina, M., Champ, J.L., Doublier, and Lecannu, G. (1990). Action of guar gums on the viscosity of digestive contents and on the gastrointestinal motor function in pigs. Digestion 46: 205-213.

Christopher, D., Pierre, C. and Claude, C. (1997). The Impact of Livestock and Fisheries on Food Availability and Demand in 2020. American Journal of Agricultural Economics 79 (5): 1471-1475.

Close, W.H. (1993). Fibrous diets for pigs. Animal Production in Developing Countries 16: 107-117

Desehinwa, A. and Ogunmodede B.K. (1999). Swine feeds and practical feed composition techniques, In: N.A.E.R.L.S. Workshop training Manual, Moor Plantation, Ibadan, April 3-7, 1995; Nat. Pig Prod. pp. 27-56.

D'Mello, J. P. F. (2003). Adverse effects of amino acids. In Amino Acids in Animal Nutrition, 2nd Edition (Ed. J. P. F. D'Mell0). CAB International, Wallingford, pp. 125-142.

FAOSTAT (2012). FAOSTAT data. Available at http://faostat.fao.org/site/291/defualt.aspx

Ferris, D.A., Flores ,R.A., Shanklin, C.W. and Whitworth, M.K. (1995). Proximate analysis of food service wastes. Applied Engineering in Agriculture 11: 567-572.

Fisher, C., Boorman, K.N. (2003). Nutrient Requirement of monogastric animals and Nutritional Research. Poultry Science Symposium No 19. pp. 47-51. Butterworth, London.

Food and agriculture organization (FAO) (2011). Mapping supply and demand for animal- source foods to 2030. Animal production and Health working paper No. 2, FAO, Rome, Italy. http://www.fao.org/ag/againfo/ resources/documents/latest- pubs/al747eoo.pdf 
Tesfaye Amene et al.,

Food and agriculture organization (FAO) (2004). The State of the Food Insecurity in the World 2004 FAO, Rome. Available online at: ftp://ftp.fao.org/docrep/fao/007 ly5650e/y5650e00.pdf .

FAO, IFAD and WFP .(2013). The State of Food Insecurity in the World 2013. The multiple dimensions of food security. Rome, FAO. www.fao/docrep/018/i3434e.pdf

Noblet, J. and LeGoff, G. (2001). Effect of dietary fibre on the energy value of feeds for pigs. Animal Feed Science and Technology 90:35-52.

Jorgensen, H., Zhao, X.Q., Knudsen, K.E.B. and Eggum, B. O. (1996). The influence of dietary fibre source and level on the development of the gastrointestinal tract digestibility and energy metabolism in broiler chickens. British Journal of Nutrition 75: 379-395.

Klinger, S.A., Block, H.C. and McKinnon, J.J. (2007). Nutrient digestibility, fecal output and eating behavior for different cattle background feeding strategies. Canadian Journal of Animal Science 87: 393-399.

Kornegay, E.T, Vander, Noot, K.M., Barth, G., Garber, W.S., MacGrath, R.L., Gil-breath, and Bielk, F.J. (1970). Nutritive evaluation of garbage as a feed for swine; Bull no. 829. College of Agricultural and Environmental Sciences, New Jersey Agricultural Experiment Station, Rutgers

Kyriazakis, I., Emmans, G.C. and Whittemore, C.T. (1990) Diet selection in pigs: choices made by growing pigs given foods of different protein concentrations. Animal Production 51:189-199.

Lawrence, B.V., Adeola, O. and Cline, T.R. (1994). Nitrogen utilisation and lean growth performance of $20-$ to $50-\mathrm{kg}$ pigs given diets balanced for lysine: energy ratio. Journal of Animal Science 72: 2887-2895.

Lee, K.H., Lee, S.K. Kim, Y.K., Cha, Y.H. and Chung, W.T (1998). Chemical composition of dried food waste meal (I). Kor. J. Anim. Nutr. Feed 22(2): 87-94.

Lebret, B. (2008). The response of various muscle types to a restriction realimentation feeding strategy in growing pigs. Journal of Animal Science, 2: 849-857.

Lindberg, J. E. (2014). Fiber effects in nutrition and gut health in pigs. Lindberg Journal of Animal Science and Biotechnology 5: 15.

Longe, O.G. and Fagbenro-Byron, V. (1990). Composition and some physical characteristics of some fibrous wastes and by-products for pig feed in Nigeria. Bietr. Trop. Landarietsch Vet. Med., 28:199-205.

Luu Huu, M., Nguyen, N. D. and Lindberg, J .E. (2003). Effects of replacement of fish meal with rice distiller's waste (hem) on performance and carcass quality of growing pigs. In: Reg Preston and Brian Ogle edns "Sustainable Livestock Production on Local Feed Resources" Proceedings.

Luu, H. M., Tran C. B., Nguyen, N. X. D. and Bui, P. T. H. (2000). Composition and nutritive value of rice distillers' by-product (hem) for small-holder pig production. Sustainable Livestock Production on Local Feed Resources. Proceedings National Seminar- Workshop. UAF, SIDA-SAREC.

Margareth, M., Kjel-Arne, R. and Anders, S. (1999). High-fat diets improve the performance of growing-finishing pigs. Acta Agriculturae Scandinavica Sect. A. Animal Science. 49:83-88

McDnald, P., Edwards, R.A., Greenhalgh, G.F.D., Morgan, G.A., Sinclair, L.A., and Wilkinson, R.G.(2007). Animal Nutrition, $7^{\text {th }}$ edition. Pp: 341-343, 461-462.

MERCK and CO., INC. (2008). Whitehouse Station, NJ USA. Published in educational partnership with Merial Ltd.
Sci. Technol. Arts Res. J., Jan-March 2016, 5(1): 27-34

Mishra, B. B., Heluf, G., Kibebew, K., Mohammed, A. and Bruk, E .(2004). Soil and land resource inventory at the Alemaya University research farm with reference to land evaluation for sustainable agricultural management and production. In: Heluf G/Kidan, and Mishra, B.B. (eds.). Specific features and management options of soil and land resources of eastern Ethiopian highlands for sustainable agricultural production. Synthesis of working papers. Dire Dawa, Ethiopia: Alemaya University: Soil Science Bulletin, p.1

Mosenthin, R., Hambrecht, E. and Sauer, W. C. (2001). Utilisation of different fibres in piglet feeds. In: Recent Develop. in Pig Nutrition . Eds. P.C. Gransworthy and J. Wiseman. Nottingham University Press, Nottingham

Myer, R.O., Brendemuhl, J.H. and Johnson, D.D. (1999). Evaluation of dehydrated restaurant food waste products as feedstuffs for finishing pigs. Journal of Animal Science 77: 685-692.

NRC .(1998). Nutrient Requirements of Swine. $10^{\text {th }}$ ed. Natl. Acad Press, Washington, DC.

Peterson, L.A. (1967). Growth and carcass comparisons of swine fed a concentrate ration, cooked garbage and additional protein, vitamin and mineral supplements. MSc. Thesis Univ. of Connecticut, Storrs

Pond, W. G. and Maner, J. H. (1984) Swine Production and Nutrition. AVI Publishing Co., pp 336-368; Westport

Qin, G.X., Xu, L.M., Jiang, H.L., Vander, P., Bosch, M.W. and Verstegen, M. W. A. (2002). The effects of Chinese and Argentine soyabeans on nutrient digestibility and organ morphology in Landrace and Chinese Min pigs. AsianAustralasian Journal of Animal Sciences 5:555-564.

Revell, D. K., Williams, I. H. (1993). A review of physiological control and manipulation of voluntary food intake. In: Manipulating Pig Production (MPP) IV, ed. E.S. Batterham. APSA, Attwood, Vic., pp. 55-80, Australia

Rivas, M.E., Brendemuhl, J.H., Johnson, D.D. and Myer, R. O. (1994). Digestibility by Swine and Microbiological Assessment of Dehydrated Edible Restaurant Waste. Res. Rep. Al-1994-3. College of Agriculture. Florida Agricultural Experiment Station. University of Florida, Gainesville

SAS .(2008). Statistical Analysis System, version 9.1, Institute, Inc., Cary, NC, USA

Shurson, G.C. (2003). Distiller's dried grains with solubles (DDGS) suited for swine may help ileitis resistance. Feedstuffs. 26:11-13.

Upton, M. (1979). Farm Management in Africa; the principle of production and planning. Oxford University Press, $p$ 298; Great Britain

Westendorf, M.L. (2000). Food waste as swine feed. In Food Waste to Animal Feed. M. L. Westendorf (Ed.). p69; lowa State Univ., Ames, IA

Westendorf, M.L., Dong, Z.C. and Schoknecht, P.A. (1998). Recycled cafeteria food waste as a feed for swine: nutrient content, digestibility, growth, and meat quality. Journal of Animal Sciences 76: 3250.

Westendorf, M. L. and Zirkle, E. W. (1997). Closing the loop with animals. Biocycle: The Journal of Compost Recycling 38(4): 51.

Westendorf ,M.L, Zirkel, E.W. and Gordon, R.(1996). Feeding food or table waste to livestock. Professional Animal Scientist 12:129-137.

Whittemore, C. T. (1993). The Science and Practice of Pig Production. Longman Scientific \& Technical, England.

Wiseman, J. (1987). Feeding of non-ruminant livestock. Butterworth and C. Ltd. p 370. 